\title{
PROPOSED RESEARCH ON THE RELATIONSHIPS BETWEEN INNOVATION COMPETITIVENESS AND EXPORT COMPETITIVENESS IN CENTRAL AND EASTERN EUROPEAN COUNTRIES*
}

\author{
Marcin Salamaga, Ph.D., Associate Professor \\ Cracow University of Economics \\ Department of Statistics \\ Rakowicka 27, 30-510 Kraków, Poland \\ e-mail: salamaga@uek.krakow.pl \\ ORCID: 0000-0003-0225-6651
}

Received 28 November 2019, Accepted 15 September 2020

\begin{abstract}
Research background: In the contemporary world, innovations are the driving force of economic development and new products, designs, trademarks and creative projects are of key importance to everyday economic decisions. Both economic theories and empirical research concern relations between innovations and foreign trade. This article belongs to this research trend and is devoted to an analysis of relations between innovations and export competitiveness in selected Central and Eastern European countries.

Purpose: The paper is aimed at assessing the impact of innovation competitiveness on export competitiveness in selected countries of Central and Eastern Europe.

Research methodology: The paper contains an analysis with the use of standardised innovation competitiveness and export competitiveness indices. Countries and industry sectors are analysed in terms of the frequency of occurrence of these indices with various combinations of their signs. The impact of innovation competitiveness on export competitiveness has been tested using dynamic models of panel data.

Results: The conducted research indicates that technological advantage usually has a considerable positive impact on the trade competitiveness of Central and Eastern European countries but the strength of the impact depends on the branch of industry. Generally, the influence of technological competitiveness on trade competitiveness is stronger in highly and moderately technologically advanced industries than in industries characterised by low technological advancement.

Novelty: The evaluation of the influence of innovation competitiveness on export competitiveness in Central and Eastern European countries using standardised competitiveness indices and a dynamic model of panel data is an added value in the paper.
\end{abstract}

\footnotetext{
* The publication was financed from funds allocated to the Faculty of Management (Cracow University of Economics) within grants to maintain research capacity.
} 
Keywords: export competitiveness, innovation gap, panel data model, technological gap theory

JEL classification: B17, O3, C23

\section{Introduction}

The competitiveness of a country may be defined as its capacity to cope with international competition and to keep a high level of domestic demand without a deteriorated current account balance.Intheinternationalmarket, itisexpressedby theacceptanceofproducts fromagivencountry and its increased share in export markets (Olczyk, 2008). The competitiveness of the economy may be considered from various perspectives, for example as technological competitiveness, capacity competitiveness, export competitiveness, and demand competitiveness. Technological competitiveness ${ }^{1}$ may be understood as a capacity to compete effectively in a particular country, coupled with the level and dynamics of innovations in that country. Thus, innovations and the related knowledge-based economy belong to the key elements supporting modern and effective technologies. Innovation is defined in various ways but the majority of definitions stress the fact that innovation is a capacity to create new ideas or products, to improve existing products, to enhance production methods, organisation and logistics, etc. In practice, innovations in products or processes can be encountered. Product innovations involve the introduction of a new product which differs from the current products in terms of its intended use or which has completely new properties and functions (GUS, 2019). Process innovations occur if production technologies are enhanced, modern software is used in the production process, improved methods are used in services, in supplies, IT or accounting services, etc. Export competitiveness is a capacity to strengthen and increase the share in sales in foreign markets thanks to price advantage, cost advantage, increased production efficiency, flexibility in the adaptation of the production structure to the changing global demand. In open economies, there are multi-directional links of different intensity between the competitiveness of various economy types. One possible dependency is the relation between the level of technological competitiveness in the economy and export competitiveness. The question arises: does the increase in technological competitiveness (innovation) affect a country's export competitiveness and to what extent?

\footnotetext{
${ }^{1}$ In some papers (including this one) the notion of technological competitiveness is used interchangeably with innovation competitiveness, even though in general the meaning of the notion of innovations is different from and broader than the notion of technology.
} 
Results of analyses of dependencies between technological competitiveness and foreign trade (rather than export competitiveness) are frequent in the relevant literature. But it is the export competitiveness which determines the international commercial position of a country. The fact that there is no broader research on relations between competitive innovations and technological innovations encourages research in this respect. The paper is aimed at the empirical verification of dependencies between innovation competitiveness and export competitiveness based on the example of Central and Eastern European countries. The constructed export competitiveness and innovation competitiveness indices as well as dynamic panel models have been used for the verification. The research hypothesis is as follows: the impact of innovation competitiveness on export competitiveness depends on the country and type of industry. Research has been conducted for various industry branches in selected Central and Eastern European countries to enable evaluation in terms of sensitivity to the impact of innovations on a country's export competitiveness. Such knowledge will allow for identifying industry branches in which investments in innovations increase the competitiveness of foreign trade to the greatest extent.

\section{Literature review}

The relation between foreign trade and innovations is an important element in certain theories of international economics, for example, Posner's Technology Gap Theory (1961), Vernon's Product Life-Cycle Theory (1966) or new theories of international trade (Cieślik, 2000). The common characteristic of the majority of these theories lies in the assumption that differences in innovation levels between countries create trade. The intensity and direction of trade change over time if the international distance in innovation level also changes (as a result of imitating innovative countries or through the spread of technologies, etc.). The links between innovation and foreign trade are also frequent subjects of empirical research. Research is conducted here on the level of countries which belong to specific economic groups or regions. Research on OECD member states was conducted, for example, by Soete (1981), Dosi, Pavitt, and Soete (1990) while research on economies of the Far East was conducted by Uchida and Cook (2003). They found a strong dependency between competitiveness in trade and technological advantage. Numerous studies also take into account macroeconomic variables other than innovation and foreign trade (Soete, Verspagen, 1994; Wakelin, 1998; Barcenilla, Lopez-Pueyo, 2000; Milberg, Houston, 2005). The results of certain studies show that the contribution of individual macroeconomic variables to the explanation of export competitiveness depends on the considered branch of the economy (Uchida, Cook, 2004). There are also papers including research on a microeconomic 
level (examination of enterprises) (Cleridesa, Lacha, Tybouta, 1998). Researchers have proved that enterprises which export their goods are characterised by greater efficiency than enterprises based on the internal market only. Some researchers inspired by Posner's theory (1961) analysed the influence of the technology gap on foreign trade (Dosi, Soete, 1983; Milberg, Houston, 2005; Granda, Fonfría, 2009). Such research conducted for OECD countries at the level of economy sectors confirms that the technology gap between countries may result in an imbalance in foreign trade (Granda, Fonfría, 2009). When it comes to tools, such research usually uses regression models, especially panel data models, or dynamic autoregression models (VAR, VECM) (Granda, Fonfría, 2009; Furman, Porter, Stern, 2002) It should be noted that the value of export per capita or share of export in the GDP is most frequently taken into account in the research quoted here (Milberg, Houston, 2005; Granda, Fonfría, 2009). This does not allow for a full evaluation of a country's export competitiveness. In this paper, the author uses measures which assess export competitiveness and innovation competitiveness in a strict sense.

\section{Research methodology}

The paper is aimed at assessing the impact of innovation competitiveness on export competitiveness in selected countries of Central and Eastern Europe. One of the elementary measures of export competitiveness in a strict sense is the revealed comparative advantage index (RCA) proposed by Balassa (1965). It expresses the ratio of the export value of the analysed group of goods in a specific country in the total value of exports in that country to the share of the export value of the group of goods in question in reference countries in the total export value in these countries. It may take the following form:

$$
R C A_{i}=\frac{E x_{i j}}{E x_{j}}: \frac{E x_{i}^{R}}{E x^{R}}
$$

where:

$E x_{i j}$ - export value in $i$-th sector in $j$-th country,

$E x_{j}$ - export value in $j$-th country,

$E x_{i}^{R}$ - export value in $i$-th sector in reference countries,

$E x^{R}-$ total export value in reference countries.

One of the drawbacks of ratio (1) is that it only informs about a comparative advantage in the past but does not provide a full assessment of trade effectiveness (Misala, 2011). Moreover, ratio (1) can assume any non-negative values. The higher its value, the greater the comparative 
advantage in a particular group of goods. The fact that the ratio is non-standardised entails certain unfavourable properties which lead to its complete non-comparability in time and space (Salamaga, 2013). For this reason, the index is standardised in the paper to the range of $[-1 ; 1)$ in the following manner:

$$
S R C A_{i}=\frac{R C A_{i}-1}{R C A_{i}+1}
$$

Technology competitiveness indices may be constructed based on variables used to evaluate innovations. e.g. R\&D expenditures, employment in innovative sectors, number of patent applications, trademarks, industrial designs, scientific articles per a population of one thousand, etc. In this paper, the number of patents has been used to construct the measure of the technology gap. It seems that the number of patents belongs to the most reliable innovation measures because it identifies the effect of the innovation process. By using the variable based on the construction of the revealed comparative advantage index, the index of technology advantage has been constructed in a similar way:

$$
I C A_{i}=\frac{P_{i j}}{P_{j}}: \frac{P_{i}^{R}}{P^{R}}
$$

where:

$P_{i j}-$ number of patents in $i$-th sector in $j$-th country,

$P_{j}$ - total number of patents in $j$-th country,

$P_{i}^{R}$ - number of patents in $i$-th sector in reference countries,

$P^{R}-$ total number of patents in reference countries.

The higher the value of index (3), the higher the relative innovation advantage of the country. For the purpose of this research, values of index (3) have been standardised in the range $[-1 ; 1)$ in accordance with the following formula:

$$
S I C A_{i}=\frac{I C A_{i}-1}{I C A_{i}+1}
$$

The positions of individual countries and industry branches are analysed in this paper in terms of the combination of signs of both indices.

The dynamic model of panel data has been used to analyse dependencies between $R C A$ and $I C A$ indices. This resulted, on the one hand, from the panel nature of data (values of $S R C A$ and SICA indices in countries of Central and Eastern Europe noted in each year during the period 2001-2018), and, on the other hand, from the need to take account of the influence 
of historic export competitiveness on current export competitiveness. The output version of the dynamic model of panel data is as follows:

$$
R C A_{m t}^{(i)}=\beta_{0}^{(i)}+\varphi^{(i)} R C A_{m t-1}^{(i)}+\beta_{1}^{(i)} I C A_{m t}^{(i)}+\varepsilon_{m t}
$$

where:

$R C A^{(i)}{ }_{m t}$ - vector of the $R C A$ index value in $i$-th group of goods for $m$-th level in period $t$, $R C A^{(i)}{ }_{m t-1}$ - vector of the $R C A$ index value in $i$-th group of goods for $m$-th level in period $t-1$, $I C A_{m t}^{(i)}$ - vector of the $I C A$ index value in $i$-th group of goods for $m$-th level in period $t$, $\beta_{0}^{(i)}, \varphi^{(i)}, \beta_{1}^{(i)}$ - model parameters,

$\varepsilon_{m t}-$ the vector of the value of the error term for the $m$-th level in the period $t$.

The estimation of equation (5) was performed using a two-level method of moments (GMM), whose effectiveness is confirmed by various research studies with the use of dynamic panel models. The GMM method allows for limiting the problem of dependent variables and correlation of variables with the effects of random components. Data used in calculations has been retrieved from the Comext (Eurostat) database while data concerning patents (registered under the Patent Cooperation Treaty (PCT)) from the database of the World Intellectual Property Organization (WIPO). The research has covered ten countries of Central and Eastern Europe and the period of 2001-2018.

\section{Results of empirical research}

In the first stage of the research, the relation between innovation competitiveness and export competitiveness for Central and Eastern European countries has been checked. For this purpose, each country has been analysed in terms of the annual occurrence of each of four possible combinations of SICA and SRCA index signs during the analysed period: 1 . SICA $\geq 0$ and $\mathrm{SRCA} \geq 0,2 . \mathrm{SICA}<0$ and $\mathrm{SRCA} \geq 0,3 . \mathrm{SICA}<0$ and $\mathrm{SRCA}<0,4$. SICA $\geq 0$ and $\mathrm{SRCA}<0$. The presence of the country in the first and third area indicates that the occurrence of innovation advantage (or lack of innovation advantage) in a specific group of goods coincides with the occurrence of export comparative advantage (or lack of comparative advantage). The analysis has been performed for industry branches which represent a varied level of technological advancement, but more detailed results are presented for examples of representatives of highlyand low-advanced technology branches, i.e. the transport equipment industry, and the food and agricultural industry, respectively. Subsequently, the collective analysis has been performed for 
all industry branches in terms of the occurrence of innovation advantage and export advantage. Figure 1 and Figure 2 contain histograms which illustrate the frequency of occurrence of countries for each combination of SRCA and SICA signs for goods produced by the transport equipment industry and goods produced by the food and agricultural industry.

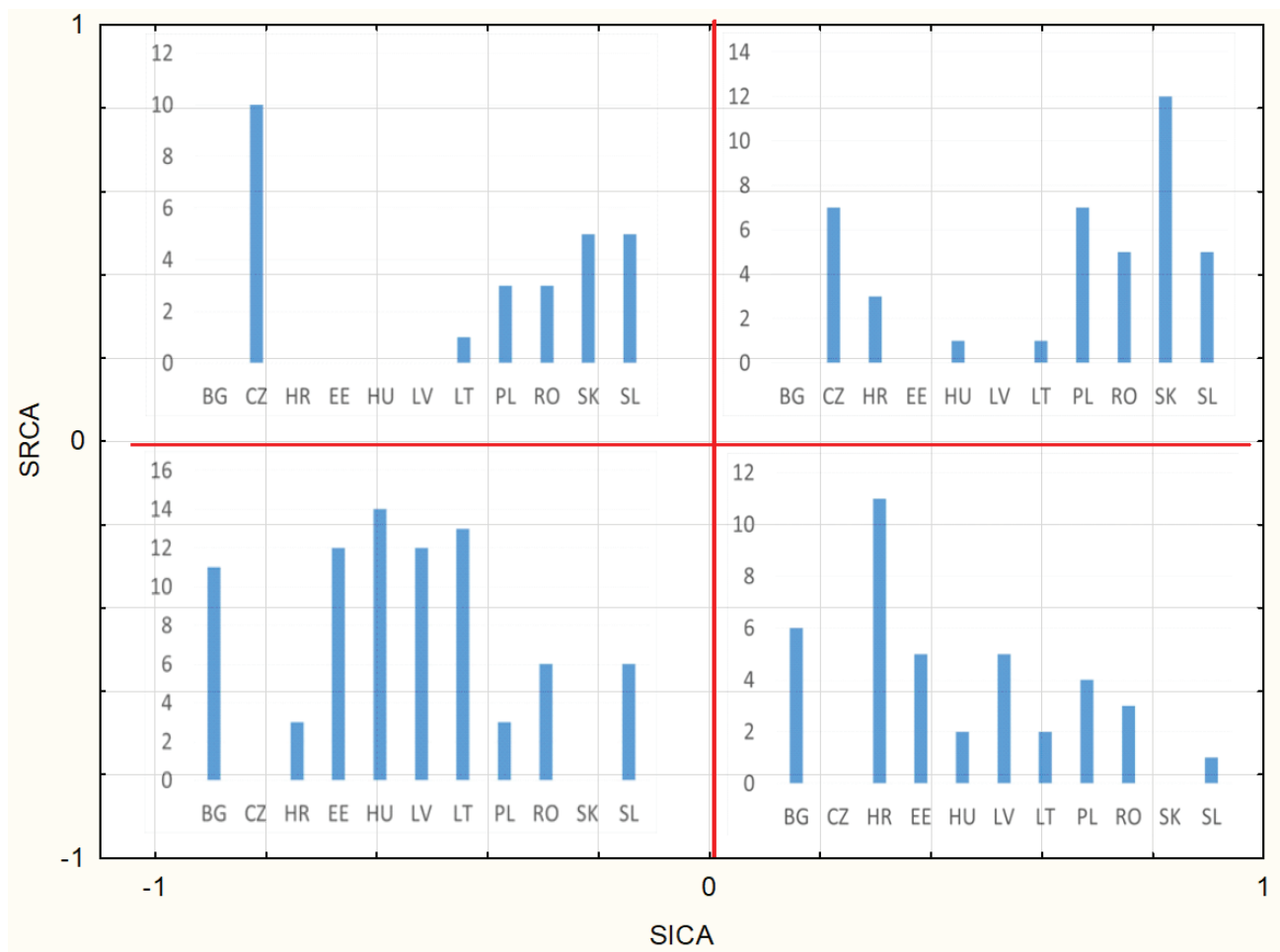

Figure 1. The frequency of occurrence of countries for various combinations of SRCA and SICA signs in the trade in goods produced by the transport equipment industry in Central and Eastern European countries during the period 2001-2017

Source: own elaboration based on Comext and WIPO.

Figure 1 indicates that Slovakia, the Czech Republic and Poland were among the countries which exhibited innovation advantage and comparative advantage in the export of products manufactured by the transport equipment industry most frequently during the analysed period. Countries with no relative innovation advantage and with no export advantage in the products of this type were usually Bulgaria, Estonia, Hungary, Lithuania, and Latvia. The Czech Republic is one of the countries which do not have innovation advantage but have comparative advantage in the export of the transport equipment industry products. Croatia, in turn, is distinguished by innovation advantage but it has no export advantage. 


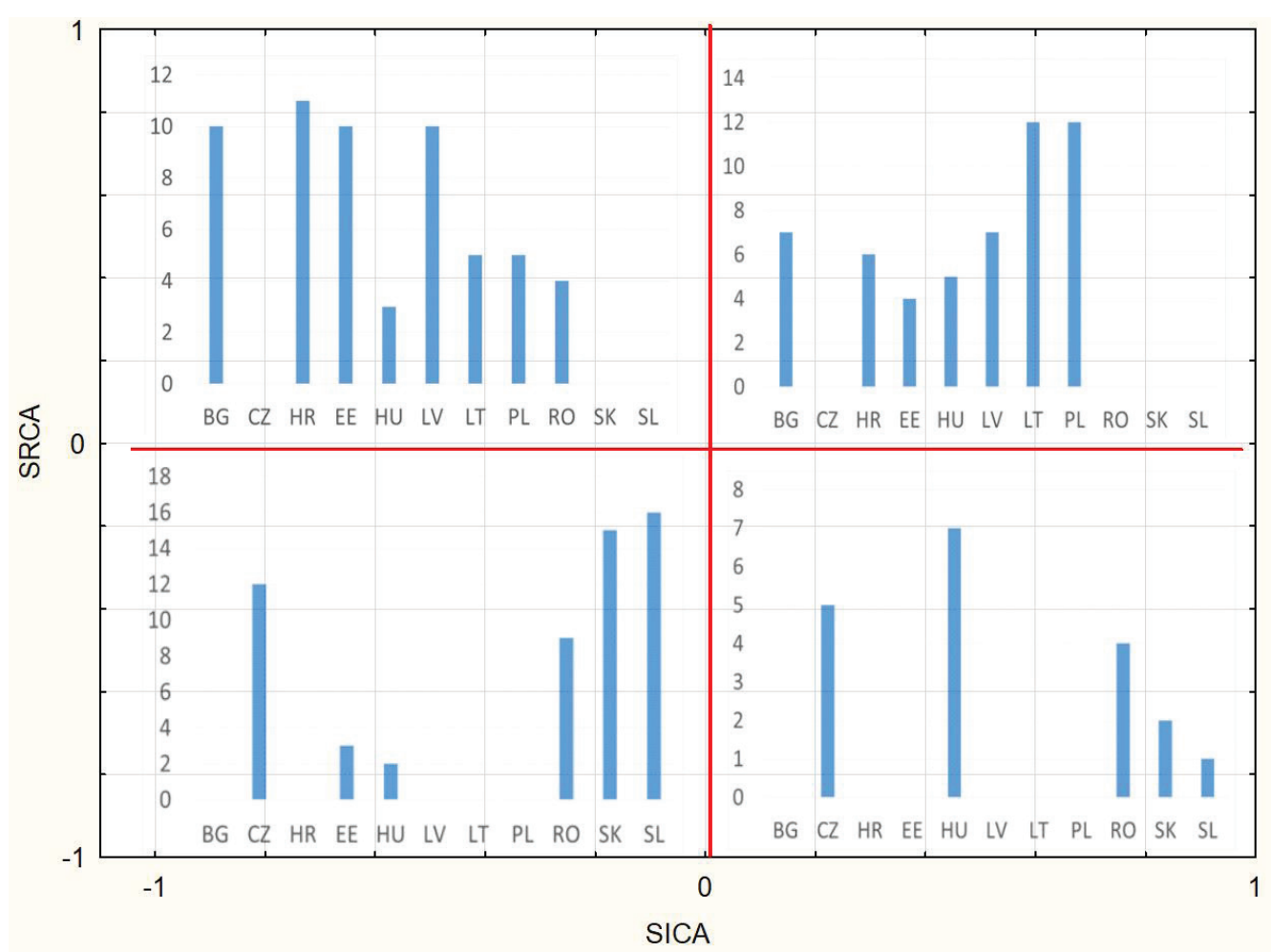

Figure 2. The frequency of occurrence of countries with various combinations of SRCA and SICA signs in the trade in products of the agricultural and food industry in Central and Eastern European countries during the period 2001-2017

Source: own elaboration based on Comext and WIPO.

Based on Figure 2 it can be concluded that during the analysed period Lithuania, Poland and Croatia had the greatest innovation and comparative advantage in the export of products manufactured by the agricultural and food industry. In contrast to that, Slovakia, Slovenia and the Czech Republic usually did not have innovation and export advantage in the scope of products of this type. Croatia belonged to the countries which most frequently did not have innovation advantage but had comparative advantage in the export of products of the agricultural and food industry. Hungary was one of the countries exhibiting innovation advantage but having no export advantage. Table 1 shows the frequency of occurrence of various branches with different combinations of SRCA and SICA signs in Central and Eastern European countries during the period 2001-2017. 
Table 1. The frequency of occurrence of various branches with different combinations of SRCA and SICA signs in Central and Eastern European countries during the period 2001-2017 (\%)

\begin{tabular}{|l|c|c|c|c|}
\hline \multicolumn{1}{|c|}{ Industry } & $\begin{array}{c}\text { STCA } \geq 0, \\
\text { SRCA } \geq 0\end{array}$ & $\begin{array}{c}\text { STCA }<0, \\
\text { SRCA } \geq 0\end{array}$ & $\begin{array}{c}\text { STCA } \geq 0, \\
\text { SRCA }<0\end{array}$ & $\begin{array}{c}\text { STCA }<0, \\
\text { SRCA }<0\end{array}$ \\
\hline Agri-food & 28.34 & 31.02 & 10.16 & 30.48 \\
\hline Fuel, energy and mineral & 30.48 & 26.20 & 17.11 & 26.20 \\
\hline Chemical & 22.99 & 27.27 & 13.90 & 35.83 \\
\hline Light & 21.39 & 34.76 & 19.25 & 24.60 \\
\hline Wood and paper & 26.20 & 34.22 & 13.37 & 26.20 \\
\hline Metallurgy and metal & 30.48 & 31.02 & 6.95 & 31.55 \\
\hline Machine & 6.42 & 18.72 & 43.85 & 31.02 \\
\hline Electrical, electronic and precision & 19.79 & 11.76 & 37.43 & 31.02 \\
\hline Vehicle manufacturing & 21.93 & 14.44 & 20.86 & 42.78 \\
\hline Other products & 16.04 & 15.51 & 29.41 & 39.04 \\
\hline
\end{tabular}

Source: own calculations based on Comext and WIPO.

Table 1 shows that innovation advantage and export advantage were mainly noted in the analysed EU countries in the metallurgy and metal industries, and in the agricultural and food industry. The absence of both kinds of advantage is most typical of the transport equipment industry and other groups of goods. The occurrence of export advantage with the simultaneous absence of innovation advantage was most typical of light industry, and the wood and paper industry. The occurrence of innovation advantage with the absence of comparative advantage was typical of the machine industry, the electric industry, the electronic industry, and precise engineering. Table 2 shows the results of the evaluation of dynamic parameters for dynamic panel data models (5) for individual EU countries.

Table 2. The estimation results of dynamic models of panel data

by Central and Eastern European countries during the period 2001-2017

\begin{tabular}{|c|l|c|c|c|}
\hline \multicolumn{1}{|c|}{ Country } & Explanatory variable & Parameter & Z & p-value \\
\hline \multirow{2}{*}{1} & \multicolumn{1}{|c|}{2} & 3 & 4 & 5 \\
\hline \multirow{3}{*}{ Bulgaria } & const & & 0.012 & 0.990 \\
\cline { 2 - 5 } & RCA (-1) & 0.968 & 2.514 & 0.012 \\
\cline { 2 - 5 } & ICA & -0.001 & -4.088 & 0.000 \\
\hline \multirow{3}{*}{ Czech Republic } & const & 0.175 & 0.803 & 0.422 \\
\cline { 2 - 5 } & RCA (-1) & 0.816 & 3.536 & 0.000 \\
\cline { 2 - 5 } & ICA & -0.002 & -0.018 & 0.895 \\
\hline
\end{tabular}




\begin{tabular}{|c|c|c|c|c|}
\hline 1 & 2 & 3 & 4 & 5 \\
\hline \multirow{3}{*}{ Croatia } & const & 0.229 & 1.431 & 0.152 \\
\hline & $\operatorname{RCA}(-1)$ & 0.791 & 4.782 & 0.000 \\
\hline & ICA & -0.008 & -0.453 & 0.651 \\
\hline \multirow{3}{*}{ Estonia } & const & 0.255 & 14.294 & 0.000 \\
\hline & $\operatorname{RCA}(-1)$ & 0.761 & 4.635 & 0.000 \\
\hline & ICA & 0.027 & 11.565 & 0.000 \\
\hline \multirow{3}{*}{ Hungary } & const & 0.238 & 7.760 & 0.000 \\
\hline & $\operatorname{RCA}(-1)$ & 0.632 & 15.664 & 0.000 \\
\hline & ICA & 0.067 & 12.843 & 0.000 \\
\hline \multirow{3}{*}{ Latvia } & const & 0.078 & 1.359 & 0.174 \\
\hline & $\operatorname{RCA}(-1)$ & 0.908 & 16.940 & 0.000 \\
\hline & ICA & 0.029 & 13.811 & 0.000 \\
\hline \multirow{3}{*}{ Lithuania } & const & -0.004 & -0.036 & 0.972 \\
\hline & RCA (-1) & 0.994 & 10.570 & 0.000 \\
\hline & TCA & 0.003 & 5.071 & 0.000 \\
\hline \multirow{3}{*}{ Poland } & const & 0.179 & 0.468 & 0.640 \\
\hline & $\operatorname{RCA}(-1)$ & 0.803 & 2.054 & 0.040 \\
\hline & ICA & 0.029 & 13.811 & 0.000 \\
\hline \multirow{3}{*}{ Romania } & const & 0.022 & 0.101 & 0.920 \\
\hline & $\operatorname{RCA}(-1)$ & 0.951 & 4.205 & 0.000 \\
\hline & ICA & 0.014 & 2.159 & 0.031 \\
\hline \multirow{3}{*}{ Slovak Republic } & const & 0.470 & 0.946 & 0.344 \\
\hline & $\operatorname{RCA}(-1)$ & 0.465 & 1.752 & 0.080 \\
\hline & ICA & 0.027 & 2.261 & 0.024 \\
\hline \multirow{3}{*}{ Slovenia } & const & 0.318 & 1.659 & 0.097 \\
\hline & $\operatorname{RCA}(-1)$ & 0.675 & 5.525 & 0.000 \\
\hline & ICA & 0.019 & 3.866 & 0.000 \\
\hline
\end{tabular}

Source: own calculations based on Comext and WIPO.

Table 2 indicates that a positive and statistically significant influence of relative innovation advantage on export competitiveness is noted in the following counties: Estonia, Hungary, Latvia, Lithuania, Poland, Romania, Slovakia, and Slovenia. The strongest influence of innovation competitiveness on export competitiveness is noted in Hungary and in Poland whereas in Bulgaria, the Czech Republic and Croatia innovation advantage does not considerably affect an increase in trade competitiveness. The influence of historic values of export competitiveness on current values of export competitiveness indices was positive and statistically significant in all 
analysed countries but the strongest impact of delayed values of the RCA index was noted in Bulgaria and Romania.

Table 3. Estimation results of dynamic models of panel data by industry types in Central and Eastern European countries during the period 2001-2017

\begin{tabular}{|c|c|c|c|c|}
\hline Industry & Explanatory variable & Parameter & z & p-value \\
\hline \multirow{3}{*}{ Agri-food } & const & 0.137 & 1.038 & 0.299 \\
\hline & $\operatorname{RCA}(-1)$ & 0.843 & 5.971 & 0.000 \\
\hline & ICA & 0.032 & 2.630 & 0.009 \\
\hline \multirow{3}{*}{ Fuel, energy and mineral } & const & 0.347 & 1.107 & 0.269 \\
\hline & $\operatorname{RCA}(-1)$ & 0.720 & 2.832 & 0.005 \\
\hline & ICA & 0.028 & 0.720 & 0.472 \\
\hline \multirow{3}{*}{ Chemical } & const & 0.427 & 0.702 & 0.482 \\
\hline & $\operatorname{RCA}(-1)$ & 0.558 & 2.390 & 0.017 \\
\hline & ICA & 0.063 & 2.113 & 0.035 \\
\hline \multirow{3}{*}{ Light } & const & -0.043 & -0.104 & 0.917 \\
\hline & $\operatorname{RCA}(-1)$ & 0.924 & 2.339 & 0.019 \\
\hline & ICA & 0.014 & 2.553 & 0.011 \\
\hline \multirow{3}{*}{ Wood and paper } & const & 0.287 & 1.418 & 0.156 \\
\hline & $\mathrm{RCA}(-1)$ & 0.878 & 12.310 & 0.000 \\
\hline & ICA & 0.029 & 2.616 & 0.009 \\
\hline \multirow{3}{*}{ Metallurgy and metal } & const & 0.135 & 1.363 & 0.173 \\
\hline & $\operatorname{RCA}(-1)$ & 0.712 & 9.874 & 0.000 \\
\hline & ICA & 0.037 & 2.773 & 0.006 \\
\hline \multirow{3}{*}{ Machine } & const & 0.129 & 0.415 & 0.678 \\
\hline & $\mathrm{RCA}(-1)$ & 0.849 & 2.398 & 0.017 \\
\hline & ICA & 0.029 & 2.616 & 0.009 \\
\hline \multirow{3}{*}{$\begin{array}{l}\text { Electrical, Electronic And } \\
\text { Precision }\end{array}$} & const & 0.231 & 1.187 & 0.235 \\
\hline & RCA $(-1)$ & 0.662 & 2.150 & 0.032 \\
\hline & ICA & 0.064 & 3.204 & 0.001 \\
\hline \multirow{3}{*}{ Vehicle Manufacturing } & const & 0.001 & 0.451 & 0.652 \\
\hline & $\mathrm{RCA}(-1)$ & 0.445 & 3.104 & 0.002 \\
\hline & ICA & 0.014 & 0.924 & 0.356 \\
\hline \multirow{3}{*}{ Other Products } & const & 0.575 & 3.666 & 0.000 \\
\hline & $\operatorname{RCA}(-1)$ & 0.297 & 1.515 & 0.130 \\
\hline & ICA & 0.024 & 1.194 & 0.233 \\
\hline
\end{tabular}

Source: own calculations based on Comext and WIPO. 
Table 2 indicates that a positive and statistically significant influence of innovation advantage is noted in seven out of ten analysed industry branches with a varied degree of technological advancement but the strongest influence of innovation competitiveness on export competitiveness is found in the chemical industry and in the wood and paper industry. Innovation competitiveness was not a statistically significant determinant of export competitiveness in the case of the fuel and energy industry, the transport equipment industry, and other products. The influence of historic values of export competitiveness on current values of export competitiveness indices was positive and statistically significant in all analysed industry branches, except for other industry branches. The influence of historic values of revealed comparative advantage on current export competitiveness was the strongest in the light industry sector and the wood and paper industry.

\section{Conclusions}

The conducted research indicates that technological advantage usually has a considerable positive impact on the trade competitiveness of Central and Eastern European countries but the strength of the impact depends on the branch of industry. Generally, the influence of technological competitiveness on trade competitiveness is stronger in highly and moderately technologically advanced industries than in industries characterised by low technological advancement. The analysis carried out by industry branches suggests that the influence of historic comparative advantage in foreign trade on the current trade competitiveness is stronger in branches with low and medium technological advancement. The comparison of these countries shows that the strongest impact of technological competitiveness on trade competitiveness is visible in Poland and in Hungary. The obtained results may help indicate branches in which increased innovations may contribute to improved trade competitiveness, and thus lead to increased sales volume. This information may be useful to those responsible for the development of a country's economic policy. This issue requires further research which will also consider other variables that can be used to evaluate innovations and export competitiveness. 


\section{References}

Balassa, B. (1965). Trade Liberalisation and 'Revealed' Comparative Advantage, Manchester School of Economics and Social Studies, 33, 99-123.

Barcenilla, S., Lopez-Pueyo, C. (2000). Macroeconomic competitiveness in the Europe of twelve: An application to 1969-1993. IAER, 6 (4), 597-618. DOI: 10.1007/BF02295372.

Cieślik, A. (2000). The new theory of foreign trade in the light of empirical research. Warszawa: Wydawnictwo Naukowe PWN.

Clerides, S., Lach, S., Tybout, J. (1998). Is learning by exporting important? Micro-dynamic evidence from Colombia, Mexico, and Morocco. The Quarterly Journal of Economics, 113 (3), 903-947.

Cook, P., Uchida, Y. (2004). The Effects of Competition on Technological and Trade Competitiveness: A Preliminary Examination, Centre on Regulation and Competition. Working Paper Series, 72. DOI: 10.22004/ag.econ.30636.

Dosi, G., Pavitt, K., Soete, L. (1990). The economics of technical change and international trade. Washington Square, New York: New York University Press.

Furman, J.L., Porter, M.E., Stern, S. (2002), The determinants of national innovative capacity. Research Policy, 31 (6), 899-933. DOI: 10.1016/S0048-7333(01)00152-4.

Granda, I., Fonfría, A. (2009). Technology and economic inequality effects on international trade. WP02/09.

GUS (2019). Science and technology in 2017. Statistical analyzes. Warszawa, Szczecin: GUS.

Milberg, W., Houston, E. (2005). The high road and the low road to international competitiveness: extending the neo-shumpeterian trade model beyond technology. International Review of Applied Economics, 19 (2), 139-161. DOI: 10.1080/02692170500031646.

Misala, J. (2011). Międzynarodowa konkurencyjność gospodarki narodowej. Warszawa: PWE.

Olczyk, M. (2008). Konkurencyjność. Teoria i praktyka. Warszawa: CeDeWu.

Posner, M.V. (1961). International trade and technical change. Oxford Economic Papers, 13 (3), $323-341$.

Salamaga, M. (2013). Propozycja modyfikacji wskaźnika ujawnionej przewagi komparatywnej z wykorzystaniem funkcji wymiernych. Zeszyty Naukowe Uniwersytetu Ekonomicznego w Krakowie, 923, 23-35. DOI: 10.15678/ZNUEK.2013.0923.02.

Soete, L. (1981). A general test of technology gap trade theory. Weltwirtschaftliches Archiv, 117, 638-660. DOI: 10.1007/BF02708115.

Soete, L., Verspagen, B. (1994). Competing for growth: The dynamics of technology gaps. In: Ll. Pasinetti, R.M. Solow (eds.), Economic growth and the structure of long term development (pp. 272-306). London: St. Martin Press. 
Wakelin, K. (1998). The role of innovation in bilateral OECD trade performance. Applied Economics, 30, 1335-1346.

Vernon, V. (1966). International investment and international trade in the product cycle. Quarterly Journal of Economics, LXXX, 190-207. 